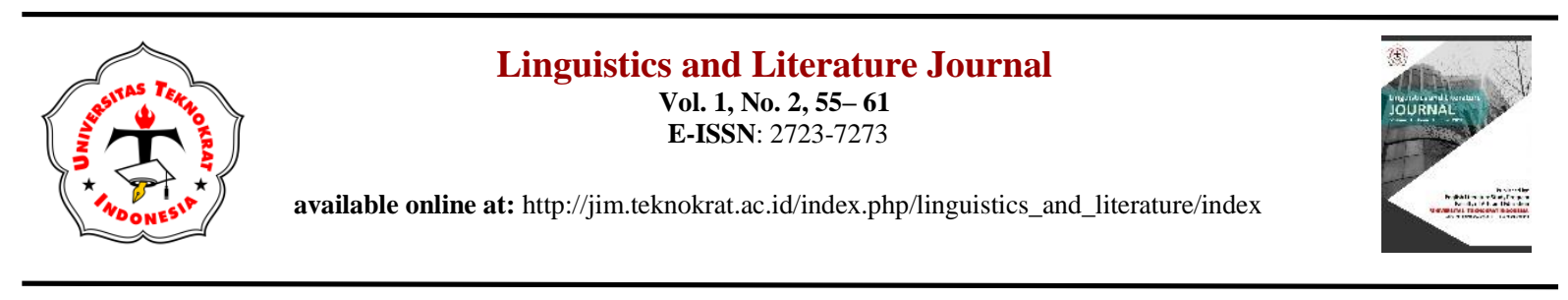

\title{
MORAL VALUES ANALYSIS IN THE FAULT IN OUR STARS NOVEL BY JOHN GREEN
}

\author{
M. Yusril Ikhja Mahendra1, Dina Amelia ${ }^{2}$ \\ Universitas Teknokrat Indonesia ${ }^{1,2}$ \\ $\underline{\text { m.yusrilikhjamahendra@teknokrat.ac.id }{ }^{1}, \underline{\text { amelia.dina@teknokrat.ac.id }}}$
}

Received: (October 2020)

Accepted: (November 2020)

Published : (December 2020)

\begin{abstract}
Moral Value is a value that affects individual and social behavior in behaving. The current study aimed to find the categories of moral values that John Green tries to convey in The Fault in Our Stars novel and to interpret its meaning by using the theory of Universal Moral Values by Kinnier et. al with four major moral values. To be able to understand moral values in the story without misinterpretation and the lessons can be applied in real life. This study used the qualitative method because it focuses on describing and interpreting the moral values in descriptive. The primary source of data is taken from the novel The Fault in Our Stars in the form of narrations and the secondary data is from previous studies in the form of statements that comes from the study findings. The results of the current study show that the categories of moral values found in the novel are (1) Commitment to something greater than oneself, (2) Self-respect, but with humility, self-discipline, and acceptance of personal responsibility, and (3) Respect and caring for others, while the moral value that is not found is (4) Caring for other living things and environment which indicates that John Green inserted moral values in the novel more about the personal lives of the characters and the relationships between them, which to civilize it, readers, to have the moral as an individual, being good to other people and to believe to something greater.
\end{abstract}

Keywords: John Green, Moral Values, The Fault in Our Stars, Universal Moral Values

\section{INTRODUCTION}

Chowdhury (2016) stated that moral with its action called morality is a human behavior towards a situation or thing and Value is the norm that is believed by society as a foundation for humans in taking action. We live where moral values commonly become the main benchmark for humans to act in daily life, there are values in social life, values in sports, values in art as including in literature. Values emerge from predecessors who came from the culture, tradition, and religious beliefs. Barcalow in Fajar (2017) describes moral as something that can be evaluated from someone's actions, and people can judge whether good or bad, morally acceptable or not, prohibited or allowed. Chippendale (2001) explains value as what is important in a person's life while Lina \& Setiawan (2017) stated that value defines right or wrong for an individual or a group. Literature and value are inseparable, each literary work must have a value that can influence its readers to behave well (Abrams, 2009). Based on those explanations, moral values focuses on the view of goodness or badness of human action and characters. Moral values could be defined as a value on how to evaluate something right and wrong and could differentiate between right or wrong of a person's behavior refer to the value used by society. In different words, Moral Value is a value that influences a person's behavior.

The level of importance in having values in life because by having them would affect one's attitude towards themself and their interaction in social life. Guerin (2001) argued that literature should be delightful and instructive. Literature as one of the major media must have a value including moral value so that a literary work not only gives its readers a pleasure but also provides values and lessons.

Literature is powerful and moral value is one of the important elements in a literary work. No exception is the literary work made by John Green, a famous writer from the United States. In his novel titled The Fault in Our Stars which tells about teenage life, he inserts a life value of struggle in life that is mostly portrayed through the characters of Hazel and Augustus. John Green is known as the writer of fiction works who focuses more on adult and teen stories. The Fault in Our Stars novel that he created is inspired by his friend who has died fighting against thyroid cancer. In the statement made by John, the reason he made this novel is to give a picture that someone who suffers from an illness does not mean to have any hope. Conversely, people with the illness are just 
the same as other healthy people where they have a desire to do an activity, even to love someone. The novel received appreciation from the public, millions of copies sold, was once the \# 1 New York Times Bestseller, \# 1 USA Today Bestseller, \#1 International Bestseller, and was awarded the Audie Award for Teens (2013).

By having the enticing story, providing insight, and getting good appreciation from the community, even being adapted into a movie in 2014 proves that there are something valuable in morality scope for many people about the story of the struggle of life in the novel, this makes the writers eager to analyze aspects of moral values contained in The Fault in Our Stars written by John Green as a focus of the current study. Generally, the novel tells about Hazel, a young 16th years old girl who struggles with cancer, in which she is not very passionate about living until it's time that a young man can inspire her to live a better life and they struggle against the disease by doing things they like such as reading novels which the stories of the novels they read are also about a girl who has cancer as a motivation.

The Fault in Our Stars novel is included popular literature, Swirski (1999) in his essay Popular and Highbrow Literature: A Comparative View describes people seeing underestimate to popular literature because of the word uses in a common language which closes to the readers, made only for pleasure, less artistic, mostly known for the mass production of it and to earn profit as much as possible. In contrast to highbrow literature or classical literature that uses more sophisticated words, is valued more, and reading the works could improve the readers intellectually. However, popular literature also provides information, knowledge, and could be as a medium to put moral values just like classical literature and civilized its readers.

This research is important to do to foster a sense of awareness for humans of the importance of having a value in life, especially morals, which organizes the way humans think, act, understand the circumstances, and to have respect for others, including respect to the opposite sex, especially to women who always seen as weak people, as stated by Aryangga \& Nurmaily (2017), women seem to have a lot of weak spots in living their roles as women assigned by their sex. It seems like women were born only to marry and breed, no more than that, this condition is of course negative, as human and God creatures, we need to respect each other regardless of looking down on a people because having something different, such different gender, religion, or other different things, we need to have a moral value to makes our behavior in positive states. Yunara \& Kardiansyah (2017) stated that people see someone's sex as an important predictor of their abilities, characters, appearances, and interests which are known as gender stereotypes. This phenomenon should not occur, there should be no gender gap, there must be not certain gender group that is considered stronger or weaker, regarding these problems, we need to have moral value so that we can have social balance, to respect others. In addition, by having a strong moral value, we as a human could influence our behavior to be a good person and having a normal personality, unlike the main character in the novel Lolita who suffer Ephebophilia, as stated by Amelia \& Dintasi (2017) An Ephebophile is someone who gains satisfaction by having a sexual fantasy towards the young girl. This research provides an understanding that having a moral value is crucial and essential for human lives to makes our attitude to be positive and minimizing a negative action and statement. Furthermore, this research was conducted to appreciate the popular literature created by authors including John Green who had entered into the 100 most influential people in the world as reported in Time Magazine in 2014. With an abundant of appreciation given by the public for the literary works that John Green has made, it indicates that his literary works, which are included as popular literature not only function to get pleasure but also provides a value and knowledge that could affect positively to the behavior and mindset of the readers.

The difference between the current study with previous studies lies in the content of moral values contained in the novel The Fault in Our Stars which tells the lives of young people struggling with cancer, it tells how to regain a life that once felt empty to be a colorful life even in imperfections condition, the story also tells about friendship and love which of course will provide variations in moral values. Moreover, each personality has its understanding of a problem and value, which of course will make a variety of interpretations among writers.

There are two research problems in the current study: (1) What are the categories of moral values that the author tries to convey in The Fault in Our Stars?, (2) How are the moral values in The Fault in Our Stars described? With the objectives (1) To find out the categories of moral values that the author tries to convey in The Fault in Our Stars, and (2) To describe moral values in The Fault in Our Stars. Theoretically, the current study provides information and descriptions of moral values contained in the novel The Fault in Our Stars. In addition, this study provides knowledge of universal moral values definition, it types and expected to be very useful for the future researcher who is interested in conducting the similar study using Kinier et al theory of Universal Moral Values and Moral Philosophical Approaches which focus on moral values interpretation in a literary work. Practically, this study provides an understanding of literature in the aspect that a novel is not just a fictional story but contains a good and moral value that can later be applied in life. For University and general students, this study is useful in understanding moral values practically by applying the knowledge and lessons contained in this study. In addition, this study is aimed at fostering a sense of appreciation for a literary work by analyzing the elements contained 
therein. Which will continue on the new literary works created by the authors because of the high sense of appreciation given.

Many researchers had been conducted on analyzing moral values in literary work, especially novels. In the current study, the writers put two previous studies that focus on the same study in interpreting moral values in a novel. There is a thesis written by Pandansari titled Moral Values Reflected Through Major Character in Shara Shepard' Pretty Little Liars in 2016 and a thesis written by Sari in 2019 entitled An Analysis of Moral Values in "Gulliver's Travel" Novel. In addition, one previous study conducted on the similar novel The Fault in Our Stars with a different focus of the study is also needed for the writers to get a deeper understanding and provides different perspective towards the story of The Fault in Our Stars novel, there is a research in the form of the journal entitled A Study on Characterization of the Main Character in The Fault in Our Stars written by Patmarinanta (2016). These studies have several relations with the current study, especially about the Universal Theory of Moral Values in Sari's, the Moral and Philosophical approach in Pandansari's and to know deeper about the novel from the aspect of characterization of characters in The Fault in Our Stars in Patmarinanta's and Ernawati's.

The writers use the theory of Universal Moral Values proposed by Kinnier et al in interpreting the values in the novel. Contemporary Writers including Krieger, Russel, and Patterson in Kinnier (2000) have argued that the future survival of humanity may depend on the acceptance of a global ethic, without it may cause those in power may simply indoctrinate the other party which has the weaker position. The call for a list of Universal moral values is has been echoed from time to time to avoid the powered one controlling the less powered. Kinnier et al did research focusing on Universal Moral Values, the theory is obtained from the conclusion of the major religious texts and literary texts regarding philosophies. There are four major Universal Moral Values; (1) Commitment to something greater than oneself, (2) Self-respect but with humility, self-discipline, and acceptance of personal responsibility, (3) Respect and caring for others, and (4) Caring for other living things and the environment. The theory of Universal Moral Values from Kinnier et al assist the writers in categorizing the moral values contained in the novel as clearly as possible, in addition by applying the theory could provide the findings of the current study be more acceptable for many groups, races, and parts of the world because it is universal. Theory of the elements in fiction work by Nurgiyantoro and Lukacs with the Theory of Novel is also used in this study to provide the understanding that moral value is included in extrinsic elements, elements that cannot be directly found in the text of a novel. Furthermore, Moral and Philosophical approaches that are derivative of literary criticism are applied in the current study. As stated by Plato in Guerin (2016) Moral and Philosophical approaches describe literature must exhibit moralism to civilized its readers. The approach itself is defined by Anthony (1963) as the level at which assumption and beliefs about something including literary work.

\section{METHOD}

The methodology used in this research is qualitative. The purpose of this methodology in the current study is to describe descriptively the moral value meaning of a text. According to Samanik \& Lianasari (2016), texts are defined broadly as books, essays, interviews, speeches, articles, and many more, in the current study, the text is in the form of a book more precisely is a novel, The Fault in Our Stars. There are two data used in this study: primary data and secondary data. The primary source of the data in this study is The Fault in Our Stars novel written by John Green. The primary data in this study are narrations related to moral values contained in The Fault in Our Stars by John Green. The secondary source of data in this study has a position as supporting data, which are something that may complete the interpretation findings of moral values. The secondary data are in the form of statements and result of a research which correlates with the current study.

The data collection technique used in this study focuses on the need for analysis which is a documented technique. Bowen (2009) describes the use of document technique is to collect the evidence of the study findings. This data collection technique aims to obtain the desired data from The Fault in Our Stars which is in the form of narration as the quotation. Documentation can be used as evidence of the analysis result. The steps of primary data collection of this study are as follows;(1) The writers read The Fault in Our Stars carefully, (2) The writers giving mark on phrases, narrations, or dialogues in The Fault in Our Stars novel that considered contains the moral value. (3) The writers make a list based on the specifications of moral values. The steps of the secondary data collection of this study are as follows: (1) The writers read a previous study that correlates with the current study. (2) The writers make a note of the needed result or statements from the sources of the secondary data.

For the data analyzing technique, the writers used the theory of data presentation analysis from Cresswell (1998), as follows: (1) Compiling and preparing data of narrations or dialogues from the novel that contains moral values. (2) Interpreting step, and correlating the result of the analysis of the moral values to the secondary data as supporting data to complete the interpretations. (3) Concluding and representing the data. The writers displayed the result of interpretation in the form of a narrative description. 


\section{FINDINGS AND DISCUSSION Categories of Moral Value as Presented in The Fault in Our Stars Novel By John Green and Directly How it Described.}

The data of the recent study is in the form of narration and dialogues are taken from The Fault in Our Stars Novel. The moral values are classified by the application of the Universal Moral Values Theory proposed by Kinnier et.al. There are four major Universal Moral Values; (1) Commitment to something greater than oneself, (2) Self-respect but with humility, self-discipline, and acceptance of personal responsibility, (3) Respect and caring for others, and (4) Caring for other living things and the environment. After the moral values are categorized, the writers direct to interpret the data. Three data are interpreted and presented in the current study, where all three occupy each category of the moral value of the four categories of the theory Universal Moral Values., while there is the type of moral values that did not found in The Fault in Our Stars Novel, the Caring for other living things and the environment category. For further explanation and discussions as following:

\section{Commitment to something greater than oneself}

Commitment to something greater than oneself is the major moral value focused on a person's behavior that belief in something greater than himself or herself. Something greater is defined to not only refer to God but also to someone or something that belief by other people has greater power than themself. There are three more specific moral values in this category (1) To recognize the existence of and be committed to a Supreme Being, higher principle, transcendent purpose or meaning to one's existence, (2) To seek the truth, and (3) To seek justice. The analysis of moral values in this category as found in the novel The Fault in Our Stars as follows:

To Recognize the existence of and be committed to a Supreme Being, higher principle, transcendent purpose or meaning to one's existence

The circle filled in with the unlucky twelve-to-eighteens, and then Patrick started us out with the serenity prayer: God, grant me the serenity to accept the things I cannot change, the courage to change the things I can, and the wisdom to know the difference. (Green, pg. 9-10)

According to the theory of Universal Moral Values by Kinnier (2000), the above quotation has a moral value that can be categorized into a commitment to something greater than oneself. More specifically, including in the category of recognizing the existence of and be committed to a supreme being, which in this case is referred to God. It can be categorized as such because the character named Patrick in the scene seems to believe in the existence of God who is depicted as the ruler and holder of all life and destiny. Behavior emitted by Patrick is an act that shows that he has morals, especially for the environment in which he lives, which in the story is described as an environment that believes in God, which is generally Christian.

Patrick is the leader of Support Group that filled by people who has an illness, the function of the group is to support each other and as seen in the quotation above, Patrick tries to make the member of the group and himself to be patient and firm, although with the condition that they have. The Support Group is also followed by the main character and the narrator, Hazel, who suffered cancer in her lung.

The moral value contained in the quotation above is to accept the existence of something greater than human, to believe in God because recognizing its existence will make people feel calmer and more accepting of their living conditions, to accept the destiny given by God, as illustrated in the novel scene. With notes, it does not mean humans only accept everything without making any effort. For example, when humans live in poverty, it does not mean accepting it forever and surrender to the situation, but rather trying to escape poverty by working harder, and when humans have worked very hard, then the concept of gratitude needs to be done for what is obtained. Refer back to the above quotation which says that "to accept the things I cannot change, the courage to change the things I can", means that as humans we need to accept things that we cannot change normally, such as the shape of human body parts, the family where we were born, or as in the novel The Fault in Our Stars, in which almost all the characters in the story have a disease that is difficult to cure. In contrast, humans can focus on things that can be changed or developed such as the level of intelligence by learning and reading books or strengthening the financial side by working harder and smarter. 


\section{Self-respect, but with humility, self-discipline, and acceptance of personal responsibility (Personal Moral Value)}

To act in accordance with one's conscience and to accept responsibility for one's behavior. In the lifetime of the human need to have personal responsibility, to control their behavior, and learn to be responsible for every action taken.

The analysis of moral values in this category as found in the novel The Fault in Our Stars as follows:

Augustus pulled out a cigarette and tapped the filter against the table. "stupid human voices always ruining everything." (Green, Pg. 164)

Based on Kinnier's theory of Universal Moral Values, the above quotation is included as a personal moral value and previously included as the moral value of to act in accordance with one's conscience and to accept responsibility for one's behavior. The reason why the moral value contained in the text is including in the category is that as portrayed in the novel, the character Augustus shows his moral reaction and behavior towards human voices that often ruined everything, ruin the other people's wish. It shows that Augustus has good morals, and it is in line with the findings of the previous study from Patmarinanta and Ernawati's work entitled A Study on Characterization of the Main Character in "The Fault in Our Stars" which said that Augustus is a loyal and kind person who always tries to make his surrounding in the positive state by doing positive action and statement.

The moral value of the text is that as humans we must keep our mouths from issuing negative words that can affect one's feelings. We must restrain and guard ourselves against issuing bad words to other people. The thing that humans can do as individuals is if we see something wrong with other people, then we need to give criticism coupled with giving solutions, not just giving negative words without giving solutions. The human need to be responsible, including the words that are said to other people, the human need to filtered the words that come out from the mouth, think first, then said, not vice versa. Having the value and implemented in human behavior will produce positive circumstances.

\section{Respect and Caring for Others}

The moral value of Respect and Caring for Others focus on a value that influences human behavior to act positively to other people. More specific moral values in this category are: To recognize the connectedness between all people, To serve humankind and to be helpful to individuals, To be caring, respectful, compassionate, tolerant, forgiving of others, and To not hurt others.

The analysis of moral values in this category as found in the novel The Fault in Our Stars as follows:

As we walked through the crowded tram, an old man stood up to give us seats together, and I tried to tell him to sit, but he gestured toward the seat insistently. (Green, pg. 161)

The action did by the old man in the story as portrayed in the quotation is include as the moral value of to be caring and compassionate to others based on Kinnier's theory, in which the old man is caring by giving a seat in a bus to Hazel and Augustus who can be seen physically has an illness, that hazel needs to always carry oxygen tanks. Although there are other people in transportation, the old man swiftly stood up and offered a seat to them. The moral value that can be taken is to give something to someone who is more in need, referring to the above quotation, specifically about giving a seat to someone who is more in need. The main point is to give something to those who need it more.

\section{CONCLUSION}

Based on the analysis of the current study of the Universal Moral Values theory proposed by Kinnier et. al. to categorize moral values contained in John Green's work The Fault in Our Stars, revealing the novel almost meet the four major categories of moral values, there is (1) Commitment to something greater than oneself, (2) Self-respect, but with humility, self-discipline, and acceptance of personal responsibility and (3) Respect and caring for others, meanwhile, moral values (4) Caring for other living things and environments are not found in the novel. Although no moral value is found to care about other creatures and the environment, it does not mean that John Green does not have the intention to invite readers to behave well in nature and the environment, but rather, this novel is more focused on the personal lives of its characters, especially the main characters, Hazel and Augustus, about their belief in something Greater, their value which is to be responsible with their actions, and to be caring and to feel sympathy to other people. Having morals as an individual is an important thing to have in life 
to keep everything in a positive state. From the results of the analysis of this study, the writers suggest the reader apply moral values and lessons that have been presented to be someone who has good behavior towards ourselves, towards others, and also trusts to something greater from us, to make our behavior is calmer, as illustrated in the novel The Fault in Our Stars by John Green.

\section{REFERENCES}

Abrams, MH. (2009). A Glossary of Literary Terms. New York: Holt, Rinehart, and WistonInc.

Amelia, Dina \& Dintasi, Febri Diantika. (2017). Ephebophilia Suffered by The Main Character in the Novel Lolita by Nabokov. Teknosastik: Jurnal Bahasa dan Sastra, 15(2), 81-86.

Anthony, Edward. M. (1963). Approach, Method, and Technique. ELT Journal, 17(2), 63-67.

Aryangga, Afri \& Nurmaily, Ely. (2017). Women's Power and Steorotype Denial in Pocahontas Movie. Teknosastik: Jurnal Bahasa dan Sastra, 15(1), 46-58.

Bowen, Glenn.A. (2009). Document Analysis as a Qualitative Research Method, Qualitative Research Journal, 9(2), 27-40.

Chippendale, P. (2001). On Values, Ethics, Morals \& Principles. https://www.researchgate.net/publication/242758616.

Chowdhury, Mohammad. (2016). Emphasizing Morals, Values, Ethics, And Character Education In Science Education And Science Teaching. The Malaysian Online Journal of Educational Science, I 4(2), 1-16.

Creswell, J.W. (1998). Qualitative Inquiry and Research Design: Choosing Among Five Traditions. London: Sage Publication.

Fajar, Syamsul. (2017). Moral Values Analysis in The Rainbow Troops Novel Written By Andrea Hirata. Darussalam: State Islamic University Ar-Rainry.

Guerin, Wilfred L et al. (2005). A Handbook of Critical Approaches to Literature. Oxford: Oxford University Press.

Hasan, M. Iqbal. (2002). Pokok-Pokok Materi Metodologi Penelitian dan Aplikasinya. Bogor: Ghalia Indonesia.

Kinnier, Richard T et al. (2000). A Short List of Universal Moral Values. (PDF) A Short List of Universal Moral Values (researchgate.net).

Lukacs, Georg. (1988). The Theory of The Novel: A Historico-philosophical essay on the form of great epic literature. London: The Merlin Press.

Lina, Desma \& Setiawan, Dwi Budi. (2017). An Analysis of Culture Shock from west to East as Seen in Reilly's The Tournament. Teknosastik: Jurnal Bahasa dan Sastra, 15(1), 14-20.

Patmarinanta A. Ernawati P. (2016). A Study on Characterization of the Main Character in The Fault in Our Stars. Journal of Research in English and Education, 1(1), 26-33.

Pandansari, Maulidya. (2016). Moral Values Reflected Through Major Character in Shara Shepard's Pretty Little Liars. Yogyakarta; Sanata Dharma University.

Samanik \& Lianasari, Fita. (2016). Antimatter Technology: The Bridge Between Science and Religion toward Universe Creation Theory Illustrated in Dan Brown's Angels and Demons. Teknosastik: Jurnal Bahasa dan Sastra, 14(2), 18-27. 
Sari, Septiyana. (2019). An Analysis of Moral Values in Gulliver's Travel Novel. Lampung; State Islamic University of Raden Intan.

Swirski, Peter. (1999). Popular and Highbrow Literature: A Comparative View. Journal of Comparative Literature and Culture, 1(4), 1-14.

Yunara, Yurisa Yulia \& Kardiansyah, M. Yuseano. (2017). Animus personality in Martin's A Song of Ice and Fire: A Game of Thrones. Teknosastik: Jurnal Bahasa dan Sastra, 15(1), 7-13. 